\title{
SKIN DECONTAMINATION WITH MINERAL CATIONIC CARRIER AGAINST SARIN DETERMINED IN VIVO
}

\author{
Ante VUČEMILOVIĆ ${ }^{1}$, Mirko HADŽIJA ${ }^{2}$, and Ivan JUKIĆ ${ }^{1}$ \\ Institute of Researches and Development of Defense Systems ${ }^{1}$, Ruđer Bošković Institute ${ }^{2}$, Zagreb, Croatia
}

Received in July 2008

Accepted in October 2008

\begin{abstract}
Our Institute's nuclear, biological, and chemical defense research team continuously investigates and develops preparations for skin decontamination against nerve agents. In this in vivo study, we evaluated skin decontamination efficacy against sarin by a synthetic preparation called Mineral Cationic Carrier $\left(\mathrm{MCC}^{\circledR}\right)$ with known ion exchange, absorption efficacy and bioactive potential. Mice were treated with increasing doses of sarin applied on their skin, and $\mathrm{MCC}^{\circledR}$ was administered immediately after contamination. The results showed that decontamination with $\mathrm{MCC}^{\circledR}$ could achieve therapeutic efficacy corresponding to $3 \mathrm{x}$ $\mathrm{LD}_{50}$ of percutaneous sarin and call for further research.
\end{abstract}

KEY WORDS: bioactive potential, $M C C^{\circledR}$, nerve agent, NOD mice, sorption powder, toxicity

Organophosphate (OP) nerve agents (G-agents and VX) are related to the OP pesticides, but have a much higher mammalian acute toxicity, particularly through skin and inhalation route (1-4).

Warfare nerve agent sarin is a codename suggested by Schrader as a derivation of Schrader, Ambros, Rüdriger and Van der Linde, who synthesised the compound. Its acute effects are primarily due to unrestricted cholinergic activity at both muscarinic and nicotinic receptors $(1,3-5)$. The threat of skin contamination by nerve agents calls for effective primary decontamination preparation for naked skin (6). Developing effective treatment and decontamination systems has proven to be a demanding task. Not only do the varying chemical properties of nerve agents impede the development of a single, "universal" decontaminant, but the extreme toxicities of these agents necessitate a matching counter-efficiency. Searching for a new decontaminant, we focused on the three main forms: 1. decontamination solutions and emulsions, 2. decontamination ointments, gels and pastes; and 3. decontamination adsorption and chemisorption powders (7).

However, many of the preparations for skin decontamination against nerve agents are toxic. Accordingly, army-issue personal decontamination kits include substances and preparations which are non-toxic, ecologically acceptable and safe $(2,8,9)$. Previous research indicated that a synthetic powder Mineral Cationic Carrier $\left(\mathrm{MCC}^{\circledR}\right)$, otherwise used as a dietary supplement, possesses ion exchange, absorption, and bioactive potential to counteract skin contamination by nerve agents (10-12).

Preclinical toxicology testing performed according to the standards and regulations of the Organization for Economic Cooperation and Development (OECD) did not indicate acute, sub-chronic, or chronic toxicity of the preparation (11), and it proved efficacious against skin contamination with warfare nerve agent sulphur mustard (13). In this study, we investigated the efficacy of $\mathrm{MCC}^{\circledR}$ against skin contamination with sarin. 


\section{MATERIAL AND METHODS}

\section{Chemicals}

Sarin was used as a contaminant in accordance with the Chemical Weapons Convention (14). The compound (isopropyl methyl phosphonofluoridate, $\mathrm{C}_{4} \mathrm{H}_{10} \mathrm{PO}_{2} \mathrm{~F}$ ) was obtained from the Laboratory for NBC Protection and Biomonitoring (Zagreb, Croatia). Solution of sarin $\left(c=100 \mathrm{mg} \mathrm{L}^{-1}\right)$ was prepared in isopropanole (Sigma, USA).

$M C C^{\circledR}$ (patent HR2002/000034) is a calcium/ sodium (30:70) powder preparation synthesised at Ruđer Bošković Institute (Zagreb, Croatia) and manufactured by KODONA (Zagreb, Croatia). Details about its form and synthesis are given elsewhere (11, 13).

\section{In vivo experiments}

Mice (NOD strain) were purchased from Ruđer Bošković Institute. The experiment included adult animals of both sexes at approximately 12 to 30 weeks of age and 28 to $32 \mathrm{~g}$ of weight. Before the experiment, the animals were kept under conventional conditions and were receiving food and water ad libitum.

The study was carried out according to the NIH Guide for the Care and Use of Laboratory Animals. Experiments received necessary approvals from the Local Ethics Committee. The day before the experiment, the mice were marked, weighed, shaved using electric shaver, and divided in groups of four. Immediately before receiving sarin, they were sedated with $35 \mathrm{mg} \mathrm{kg}^{-1} \mathrm{~b}$. w. pentobarbital sodium solution (Nembutal $^{\mathbb{R}}$, Abbot Lab., Chicago, USA). Sarin was administered on the shaved back skin of the animals in increasing volumes of ( 0 to 1.4$) \mathrm{mL}$ using a pipetman by Eppendorf. About $2 \mathrm{~g}$ of $\mathrm{MCC}^{\circledR}$ powder was sprinkled over the same site and rubbed in with a spoon one minute after contamination with sarin. The efficacy of the preparation was tested on four mice per dose and experiments were repeated twice.

To determine mortality rate in following 24 hours, animals that survived the experiment were returned to cages and kept in conventional conditions. After 24 hours the surviving animals were sedated and sacrificed.

Median lethal sarin dose $\left(\mathrm{LD}_{50}\right)$ and $95 \%$ limit of reliability $\left(\mathrm{L}_{\mathrm{R}}\right)$ were calculated from Weil's tables (15) using the following equations:

$\log \mathrm{LD}_{50}=\log \mathrm{D}_{\mathrm{A}}+\log \mathrm{G}_{\mathrm{f}}(1+\mathrm{f})$

$\log 95 \% \mathrm{~L}_{\mathrm{R}}=\log \mathrm{LD}_{50} \pm 2 \mathrm{~d} \times \sigma$
The therapeutic decontamination effect (TDE) of $\mathrm{MCC}^{\circledR}$ was calculated using the following equation: $\mathrm{TDE}=\mathrm{LD}_{50}$ (with decontamination) $/ \mathrm{LD}_{50}$ (without decontamination).

\section{RESULTS AND DISCUSSION}

$\mathrm{MCC}^{\circledR}$ is a synthetic zeolite with a threedimensional net structure and known ion exchange, absorption efficiency, and bioactive potential (9-12, 19-22). Our earlier study on CBA has shown that it is also an efficacious skin decontaminant against high doses of sulphur mustard (13). This study was performed on a similar in vivo model (NOD mice) to evaluate the efficacy of $M C C^{\circledR}$ against chemical warfare agent sarin. We applied the same array of methods as proposed in earlier research (16-19).

The median lethal dose of percutaneous sarin for NOD mice is $1221.80 \mu \mathrm{g} \mathrm{kg}-1$. According to literature data (17) it is within the $95 \%$ limit of reliability (95\% $\mathrm{L}_{\mathrm{R}}$ ) (Table 1). Animals which received the lethal or a higher dose of sarin but not $\mathrm{MCC}^{\circledR}$ died within 20 minutes. They showed tremors and convulsions immediately after sarin was applied onto the skin.

Table 2 shows the volumes of sarin solution applied on the mouse skin and detailed data on animals that survived $24 \mathrm{~h}$ after the experiment. Without decontamination, sarin caused $50 \%(2 / 4)$ and $100 \%$ (4/4) mortality in the doses of $1452.86 \mu \mathrm{g} \mathrm{kg}^{-1}$ and $1830.60 \mu \mathrm{g} \mathrm{kg}^{-1}$, respectively (Figure 1). To evaluate the efficacy of $\mathrm{MCC}^{\circledR}$ we used the same two doses of sarin and four higher doses on a second group of NOD mice. Figure 1 shows that $\mathrm{MCC}^{\circledR}$ can increase the survival of contaminated mice even at these higher doses. Mice decontaminated with $\mathrm{MCC}^{\circledR}$ tolerated the dose of $3662.68 \mu \mathrm{g} \mathrm{kg}^{-1}$, which is three times the sarin's percutaneous $\mathrm{LD}_{50}$ (Table 2). The recovered animals had no skin changes, which was confirmed 24 hours after exposure and treatment.

Together with our earlier findings (13), these results suggest that $\mathrm{MCC}^{\circledR}$ is a promising antidote against sulphur mustard and sarin because of a great absorption potential $(5,24-27)$ owed to its threedimensional net structure and micro-size inorganic particles.

\section{CONCLUSION}

Although sulphur mustard and sarin have a different molecular structure, $\mathrm{MCC}^{\circledR}$ was able to 


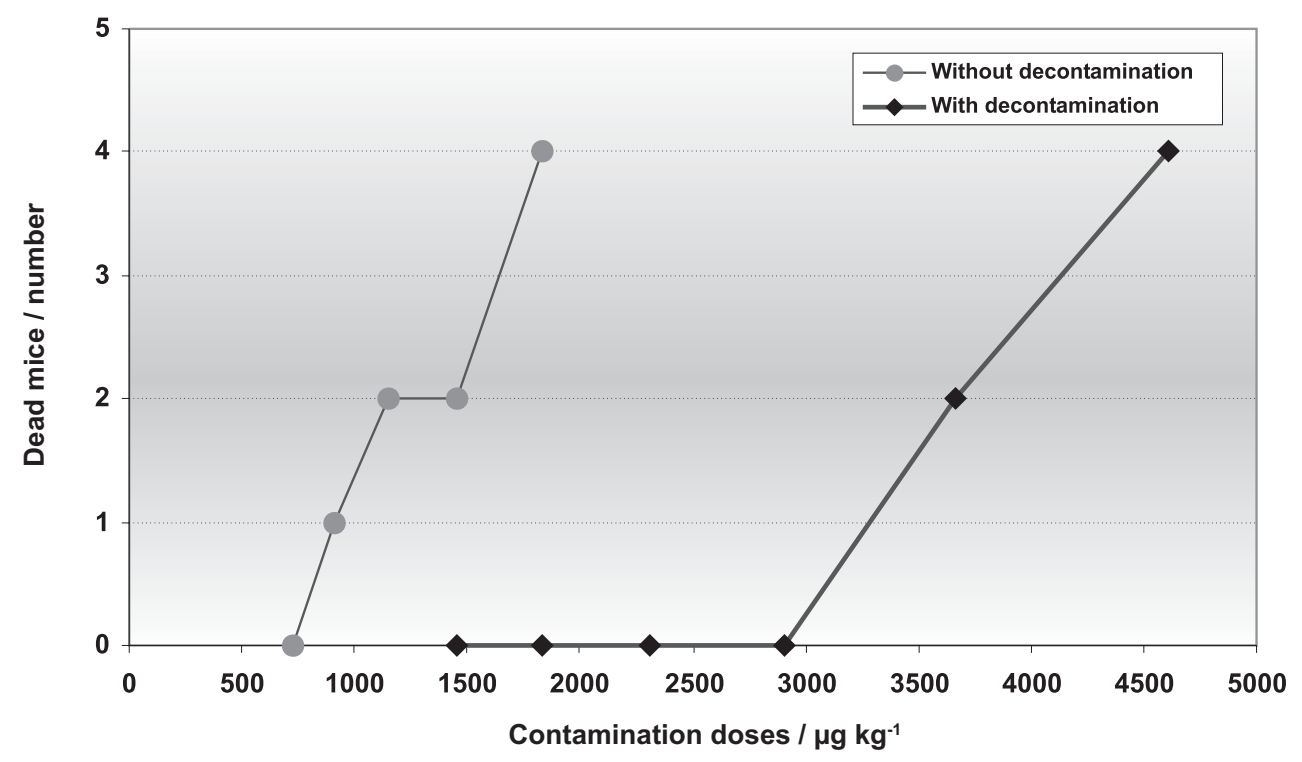

Figure 1 Mortality of mice (NOD strain) contaminated with $L D_{50}$ sarin solution in isopropanole (c=100 $\left.\mathrm{mg} \mathrm{L}^{-1}\right)$ with and without skin decontamination with $M C C^{\circledR}$

Table 1 Skin decontamination against nerve agent sarin determined in vivo.

\begin{tabular}{lccc}
\hline \multirow{2}{*}{ Group of mice } & \multicolumn{3}{c}{ Skin poisoning with sarin } \\
\cline { 2 - 4 } & $\mathbf{L D}_{\mathbf{5 0}} / \boldsymbol{\mu} \mathbf{g ~ \mathbf { ~ g } ^ { - 1 }}$ & $\mathbf{9 5} \mathbf{~ \% ~} \mathbf{L}_{\mathbf{R}} / \boldsymbol{\mu} \mathbf{~} \mathbf{~ k g}^{-1}$ & TDE \\
\hline Without decontamination & 1221.80 & 956.31 to 1560.99 & $/$ \\
With decontamination & 3662.68 & 3204.79 to 4186.01 & 3 \\
\hline
\end{tabular}

$T D E$ - therapeutic decontamination effect

$95 \% L_{R}$ - limit of reliability

Table 2 Survival of mice (NOD strain) contaminated with $L D_{50}$ sarin solution in isopropanole $\left(c=100 \mathrm{mg} \mathrm{L}^{-1}\right)$ with and without skin decontamination with $M C C^{\circledR}$

\begin{tabular}{lcc}
\hline Group of mice & $\begin{array}{c}\text { Volume of } \mathbf{L D}_{\mathbf{5 0}} \text { sarin solution } \\
\text { per mouse / } \mathbf{~ m L}\end{array}$ & D/C \\
\hline & 0.240 & $0 / 4$ \\
Without decontamination & 0.275 & $1 / 4$ \\
& 0.346 & $2 / 4$ \\
& 0.436 & $2 / 4$ \\
& 0.549 & $4 / 4$ \\
\hline & 0.436 & $0 / 4$ \\
With decontamination & 0.549 & $0 / 4$ \\
& 0.692 & $0 / 4$ \\
& 0.872 & $0 / 4$ \\
\end{tabular}

$D$ - number of dead mice, $C$ - number of contaminated mice 
absorb them, inactivate, and prevent severe poisoning in mice receiving doses as high as 8.4 and three times the respective percutaneous $\mathrm{LD}_{50}$.

Our finding speaks in favour of current research of inorganic microparticles like $\mathrm{MCC}^{\circledR}$ as reactive sorbents for the decontamination of chemical warfare agents $(20,28,29)$. However, further in vivo studies should elucidate whether the preparation is safe for extensive use in military personnel and whether it is environmentally friendly.

\section{Acknowledgements}

The authors would like to thank CODONA Zagreb and Boris Subotić for providing the $\mathrm{MCC}^{\circledR}$ preparation.

\section{REFERENCES}

1. Sidell FR. Chemical Warfare Agents. New York (NY): John Wiley \& Sons; 1996

2. Sidell FR, Takafuji ET, Franz DR, editors. Medical Aspects of Chemical and Biological Warfare. Part I. Textbook of Military Medicine. Washington (DC): Department of the Army United States of America; 1997.

3. Balali-Mood M, Shariat M. Treatment of organophosphate poisoning. Experience of nerve agents and acute pesticide poisoning on the effects of oximes. J Physiol (Paris) 1998;92:375-8.

4. Bide RW, Schofield L, Risk DJ. Immediate post-dosing paralysis following severe soman and VX toxicosis in guinea pigs. J Appl Toxicol 2005;25:410-7.

5. Yang YC, Baker JA, Ward JR. Decontamination of chemical warfare agents. Chem Rev 1992;92:1729-43.

6. Matoušek J. Sorption-mechanical principle in skin decontamination. In: Sohns T, Voicu VA, editors. NBC Risks: Current capabilities and future perspectives for protection. Dordrecht: Kluwer Academic Publishers; 1999. p. 265-9.

7. Matoušek J. Personal decontamination in cases of chemical terrorist attacks. In: Dishovsky C, Pivovarov A, Benshop H, editors. Medical treatment and decontamination of chemical agents in the area of terrorist attack. Dordrecht: Springer; 2006. p. 153-63.

8. Houston M, Hendrickson RG. Decontamination. Crit Care Clin 2005;21:653-4.

9. Trapp R. The detoxification and natural degradation of chemical warfare agents. Stockholm: Stockholm International Peace Researcher Institute (SIPRI); 1985. p. 44-7.

10. Vučemilović A, Jukić I, Subotić B, Hadžija M. The zeolites as skin decontaminants against nerve agent sarine in vivo. First World Congress on Chemical and Biological Terrorism. CBMTS - Industry II. Dubrovnik 2001. Abstracts p. 257-9.

11. Hadžija M, Križanac S. Studija akutne, subkronične i kronične toksičnosti tribomehanički aktiviranog zeolita [Acute, subchronic and chronic toxicity study of tribomechanically activated micronized mineral zeolite, in Croatian]. Research study. Zagreb: Ruđer Bošković Institute; 1999.

12. Vučemilović A. Učinci zeolita na nokse [Influence of zeolites on the noxious, in Croatian]. [MSc thesis]. Zagreb: Zagreb University Faculty of Science; 2001.
13. Vučemilović A, Hadžija M, Jukić I. Efficacy of mineral cationic carrier against sulphur mustard in skin decontamination. Arh Hig Rada Toksikol 2008;59:289-93.

14. Zakon o prihvaćanju Konvencije za zabranu kemijskog oružja [Chemical Weapons Convention Adoption Act, in Croatian]. Narodne novine 1995;(4).

15. Weil CS. Tables for convenient calculation of medianeffective dose $\left(\mathrm{LD}_{50}\right.$ or $\left.\mathrm{ED}_{50}\right)$ and instructions in their use. Biometrics 1952;8:249-63.

16. Sawyer TW, Parker D, Thomas N, Weiss MT, Bide RW. Efficacy of an oximate-based skin decontaminant against organophosphate nerve agents determined in vivo and in vitro. Toxicology 1991;67:267-77.

17. Gates M, Renshaw BC. Fluorophosphates and other phosphorus-containing compounds. In: Summary Technical Report of Division 9, Vol. 1, Parts I, II. Washington (DC): Office of Scientific Research and Development; 1946. p. 131-55.

18. Vandekar M, Komanov I, Kobrehel D. Istraživanje perkutane toksičnosti organofosfornih spojeva. 2. Učinak površine kontaminacije i koncentracije otrova na brzinu prodiranja paraoksona kroz kožu [Study of dermal toxicity of organophosphorus compounds. II. Effect of the size of the contaminated skin area and the concetration of the poison on the penetration rate of paraoxon through the skin, in Croatian]. Arh Hig Rada Toksikol 1963;14:13-8.

19. Dalton CH, Hattersley IJ, Rutter SJ, Chilcott RP. Absorption of the nerve agent VX (O-ethyl-S-[2(di-isopropylamino)ethy 1]methyl phosphonothioate) through pig, human and guinea pig skin in vitro. Toxicol in Vitro 2006;20:1532-6.

20. Christian I, editor. Sorbent Decontamination System. SDS Team Newsletter. Edgwood: Edgwood Research Development and Engineering Center; 1999.

21. Gordon RK, Feaster SR, Russell AJ, LeJeune KE, Maxwell DM, Lenz DE, Ross M, Doctor BP. Organophosphate skin decontamination using immobilized enzymes. Chem Biol Interact 1999;120:463-70.

22. LeJeune KE, Russell AJ. Biocatalytic nerve agent detoxification in fire fighting foams. Biotechnol Bioeng 1999;62:659-65.

23. Simonian AL, Grimsley JK, Flounders AW, Schoeniger JS, Cheng TC, DeFrank JJ, Wild JR. Enzyme based biosensor for the direct detection of fluorine-containing organophosphates. Anal Chim Acta 2001;442:15-23.

24. Volans AP. Sarin - Guidelines on the management of victims of a nerve gas attack. J Accident Emerg Med 1996;13:2026.

25. Wadman M. US claims of 'no chemical links' to Gulf War illnesses under fire. Nature 1997;385:187.

26. Okumura T, Hisaoka T, Yamada A, Naito T, Isonuma $\mathrm{H}$, Okumura S, Miura K, Sakurada M, Maekawa H, Ishimatsu S, Takasu N, Suzuki K. The Tokyo subway sarin attack - lesons learned. Toxicol Appl Pharmacol 2005;207: 471-6.

27. Storzbach D, Rohlman DS, Anger WK, Binder LM, Campbell KA. Neurobehavioral deficits in Persian Gulf veterans: Additional evidence from a population-based study. Environ Res 2001;85:1-13.

28. Wagner GW, Bartram PW. Reactions of VX, HD and their simulants with $\mathrm{NaY}$ and $\mathrm{AgY}$ zeolites. desulfurization of VX on AgY. Langmuir 1999;15:8113-8.

29. Wagner GW, Bartram PW, Koper O, Klabunde KJ. Reactions of VX, GD and HD with nanosize MgO. J Phys Chem 1999;103:3225-8. 
Sažetak

\section{KOŽNA DEKONTAMINACIJA ŽIVČANOGA BOJNOG OTROVA SARINA S APSORPCIJSKIM} PRIPRAVKOM U UVJETIMA IN VIVO

Istraživački tim NBKO (nuklearno-biološko-kemijske obrane) radi na pronalasku i razvoju pripravka za dekontaminaciju kože od živčanih bojnih otrova. Cilj ovog istraživanja bio je ispitati dekontaminacijska svojstva (adsorpcijska i/ili kemisorpcijska) pripravka $\mathrm{MCC}^{\circledR}$ rabeći živčani bojni otrov sarin kao kožni kontaminant u uvjetima in vivo. $\mathrm{MCC}^{\circledR}$ je sintetski pripravak koji je biokemijski aktivan i ima ionskoizmjenjivačka i adsorpcijska svojstva. Istraživanje u uvjetima in vivo napravljeno je na miševima aplikacijom rastućih doza sarina na kožu životinje. Pripravak $\mathrm{MCC}^{\circledR}$ uporabljen je kao kožni dekontaminant neposredno nakon kožne kontaminacije sarinom. Istraživanja su pokazala da pripravak $\mathrm{MCC}^{\circledR}$ posjeduje adsorpcijska svojstva, ujedno važna za dekontaminaciju živčanih bojnih otrova. Eksperimenti u uvjetima in vivo na miševima (NOD-soj) pokazali su da se dekontaminacijom pripravkom $\mathrm{MCC}^{\circledR}$ može postići terapijski učinak od $3 \mathrm{LD}_{50}$ (perkutano, sarin).

KLJUČNE RIJEČI: dekontaminacija kože, miš, pripravak Mineral Cationic Carrier (MCC ${ }^{\circledR}$ ), sarin

\section{CORRESPONDING AUTHOR:}

Ante Vučemilović, Ph.D.

Laboratory for NBC Protection and Biomonitoring Institute of Researches and Development of Defense Systems

Ilica 256b, Zagreb, Croatia

E-mail: ante.vucemilovic@inet.hr 